\title{
Árangur afnæmismeðferðar á Íslandi 1977-2006
}

\section{Sverrir Gauti Ríkarðsson ${ }^{1,2}$} læknanemi

Yrsa B. Löve 2

læknir

\section{Guðmundur $\mathrm{H}$. Jörgensen ${ }^{2}$}

læknir

\section{Davíd Gíslason ${ }^{3}$}

yfirlæknir

Björn Rúnar

Lúovíksson ${ }^{1,2}$

yfirlæknir

Lykilorð: ofnæmi, afnæmismeðferð, astmi, langtímaáhrif.

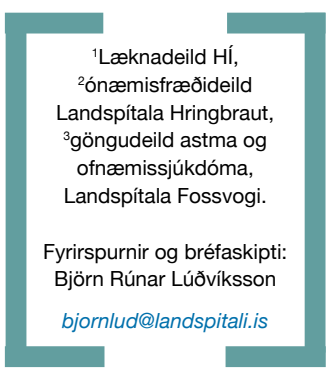

\section{Ágrip}

Inngangur: Tíðni ofnæmis hefur farið ört vaxandi á síðastliðnum premur áratugum og er nú talið að allt að 25-30\% íbúa iðnríkjanna sýni einkenni ofnæmis í einhverri mynd. Tilgangur rannsóknarinnar var að varpa ljósi á árangur afnæmismeðferðar yfir 30 ára tímabil á Íslandi. Efniviður og aðferðir: Á rannsóknartímabilinu frá 1977 til 2006 hófu 289 einstaklingar afnæmismeðferð á göngudeild astma- og ofnæmissjúkdóma á Landspítalanum. Haft var samband við 169 manns og sampykktu 128 (76\%) pátttöku í rannsókninni. Upplýsinga var aflað með stöðluðum spurningalista og aflestri sjúkraskráa. Sjúklingar voru að auki húðprófaðir. Niðurstöður: Að meðaltali voru 20 ár liðin frá lokum afnæmismeðferðar pegar árangur hennar var metinn í pessari rannsókn. Alls voru 118 (92\%) einstaklingar afnæmdir gegn vallarfoxgrasi, 39 (30\%) gegn birki, 38 (30\%) gegn köttum og 36 (28\%) gegn rykmaurum. Við endurmat sjúklinga reynust $86(67 \%)$ vera einkennalausir eða betri. Karlmenn svöruðu að jafnaði meðferð betur en konur $(p=0,04)$. Ættarsaga um ofnæmi eða astma í fyrstu gráðu ættingjum hafði jákvæð áhrif á árangur afnæmismeðferðar $(\mathrm{p}=0,02)$. Að auki var sýnt fram á að afnæmismeðferð gegn vallarfoxgrasi og rykmaurum skilaði betri árangri en afnæming gegn birki og köttum $(p=0,04)$. Meðferðin dró úr líkum á astma síðar meir.

Ályktanir: Afnæmismeðferð sem stendur yfir í 3-5 ár að meðaltali dregur almennt úr einkennum ofnæmissjúklinga til lengri tíma. Pá má leiða líkur að pví að afnæmismeðferð minnki líkur á próun nýs ofnæmis.

\section{Inngangur}

Algengi ofnæmis hefur farið vaxandi síðastliðna prjá áratugi og er nú talið að 25-30\% íbúa iðnríkjanna hafi ofnæmi í einhverri mynd. ${ }^{1}$ Ofnæmi og fylgikvillar pess eru talin vera ein algengasta orsök veikinda og fjarvista fólks frá vinnu og skóla í hinum vestræna heimi. ${ }^{1-3}$ Meðhöndlun ofnæmis byggist fyrst og fremst á prennu; fyrirbyggjandi meðferð, par sem brýnt er fyrir ofnæmissjúklingi að forðast ofnæmisvald, einkennamiðaðri meðferð og afnæmingu. ${ }^{4,5}$

Afnæmismeðferð hefur verið beitt á ofnæmissjúklinga í næstum heila öld og er hún talin vera eina meðferðin sem getur læknað ofnæmi varanlega. Meðferðin gagnast eingöngu peim sem hafa IgE-miðlað ofnæmi. Breytingar á frumusvörun T- og B-frumna við ofnæmisvaka sjást um mánuði eftir að meðferð er hafin. Meðferðin miðar að tilfærslu í ónæmiskerfinu par sem meðal annars verður breyting á T-hjálparfrumusvari 2 (TH2) yfir í T-hjálparfrumusvar 1 (TH1) sem leiðir til pess að bráđa- og seinsvörun kemur síður fram..$^{6-8}$

Sjúklingar með ofnæmi hafa aukið magn TH2 (CD4+) frumna í blóði sem rennir stoðum undir ráđandi hlutverk peirra í meingerð sjúkdómsins. Við afnæmingu myndast T-stýrifrumur (TST) sem bæla losun TH2 bólgumiðla og draga pannig úr ofnæmisviðbrögðum. TST frumur örva meðal annars myndun IL-10 sem hefur bælandi áhrif á virkni basófíla og mastfrumna. Samfara myndun pols gegn ofnæmisvakanum verður aukin framleiðsla sértækra mótefna (IgG4, IgG1 og IgA). Framleiðsla sértækra IgE mótefna minnkar og pað dregur úr ofnæmissvari. ${ }^{6-7,9}$

Meðferðinni er skipt í tvö tímabil, upphleðsluog viðhaldstímabil. Á upphleðslu-tímabilinu er ofnæmisvaka sprautað undir húð í stigvaxandi skömmtum par til viðhaldsskammti er náð. Viðhaldsskammti er yfirleitt náð með vikulegri meðferð í prjá til fjóra mánuði. Eftir pað er sá skammtur gefinn á 4-6 vikna fresti í prjú til fimm ár. ${ }^{7} 10$

Afnæmismeðferð hentar helst peim sem hafa sannarleg einkenni um ofnæmi fyrir frjókornum (gras og birki), rykmaurum, skordýrabitum (geitunga) og dýrum (köttum). ${ }^{11}$ Ráðleggingar um beitingu afnæmismeðferðar liggja fyrir á Íslandi og eru pær að hluta byggðar á erlendum ráðleggingum frá The American College of Allergy, Asthma \& Immunology (ACAAI):

Alvarleiki einkenna. Ljóst er að lífshættuleg einkenni gefa tilefni til meðferðar frekar en 
pau sem vægari eru. Pannig eiga allir sem hafa fengið ofnæmislost eftir geitungastungu að fara 1 afnæmingu.

Tímalengd einkenna. Sterkari rök eru fyrir afnæmingu fyrir grasi en birki par sem frjótími birkis hér á landi er mjög stuttur.

Hvernig gengur að forðast ofnæmisvald.

Tafla I. Lýðfræðilegar upplýsingar um pátttakendur ( $n=128)$ i rannsókn á árangri afnæmismeðferðar sem veitt var á Landspítala frá 1977 til 2006.

\begin{tabular}{|c|c|c|}
\hline & Karlar $(n=74)$ & Konur $(n=54)$ \\
\hline Meðalaldura(ár): & $21,1 \pm 8,1$ & $20,7 \pm 8,9$ \\
\hline Ár frá lokum meðferðar: & Fjöldi (\%) & Fjöldi (\%) \\
\hline -Skemur en 2 ár: & $1(1,4)$ & $1(1,9)$ \\
\hline$-2-5$ ár: & $4(5,4)$ & $6(11,1)$ \\
\hline -6-10 ár: & $3(4,1)$ & $6(11,1)$ \\
\hline -11-15 ár: & $4(5,4)$ & $5(9,3)$ \\
\hline -16-20 ár: & $13(16,2)$ & $5(9,3)$ \\
\hline -Meira en 20 ár: & $49(66,2)$ & $31(57,4)$ \\
\hline Aðrir sjúkdómarb: & $34(45,9)$ & $22(40,7)$ \\
\hline Ættarsagac: & $46(62,2)$ & $34(63,0)$ \\
\hline Reykingasaga: & $23(31,1)$ & $24(44,4)$ \\
\hline $\begin{array}{l}\text { a: Við upphaf meðferðar. } \\
\text { b: Aðrir en ofnæmi eða astm } \\
\text { c: Ofnæmi og/eða astmi me }\end{array}$ & $\begin{array}{l}\text { d. } \\
\text { tingja. }\end{array}$ & \\
\hline
\end{tabular}

Tafla II. Ofnæmiseinkenni i kjölfar afnæmismeðferðar.

\begin{tabular}{|c|c|c|}
\hline Einkenni & $\begin{array}{l}\text { Við lok meðferðar } \\
\text { Fjöldi (\%) I } \mathrm{M} \pm \mathrm{SF}^{\mathrm{b}}\end{array}$ & $\begin{array}{c}\text { Við eftirfylgda } \\
\text { Fjöldi (\%) I } \mathrm{M} \pm \mathrm{SF}^{\mathrm{b}}\end{array}$ \\
\hline Augneinkenni $(125 / 128)^{c}$ & \multicolumn{2}{|c|}{$(126 / 128)^{c}$} \\
\hline Einkennalausir & $14(11) \mid 0,4 \pm 0,5$ & $21(17) \mid 0,5 \pm 0,5$ \\
\hline Betri & $64(51) \mid 4,2 \pm 2,1$ & $67(54) \mid 3,8 \pm 1,5$ \\
\hline Óbreyttir & $42(34) \mid 8,0 \pm 1,5$ & $32(26) \mid 7,8 \pm 1,6$ \\
\hline Verri & 5 (4) | ------------ & 6 (5)। ----------- \\
\hline Nefslímhúđareinkenni $(127 / 128)^{c}$ & \multicolumn{2}{|c|}{$(128 / 128)^{c}$} \\
\hline Einkennalausir & 15 (12) | 0,3 \pm 0,5 & 18 (14) | 0,4 $\pm 0,5$ \\
\hline Betri & $63(50) \mid 4,2 \pm 2,1$ & $70(55) \mid 3,7 \pm 1,7$ \\
\hline Óbreyttir & $45(35) \mid 8,1 \pm 1,3$ & $35(28) \mid 8,0 \pm 1,4$ \\
\hline Verri & 4 (3)। ------- & 5 (4) | ------------ \\
\hline Munn- og kokslímhúð $(85 / 128)^{c}$ & \multicolumn{2}{|c|}{$(84 / 128)^{c}$} \\
\hline Einkennalausir & $13(15) \mid 0,4 \pm 0,5$ & $17(20) \mid 0,5 \pm 0,5$ \\
\hline Betri & $39(46) \mid 4,0 \pm 1,8$ & 37 (44) | 3,6 \pm 1,5 \\
\hline Óbreyttir & 30 (36) | 7,8 $\pm 1,8$ & $25(30) \mid 7,7 \pm 2,0$ \\
\hline Verri & 3 (4) | - - & 5 (6) | ---------- \\
\hline Öndunarfæraslímhúð (60/128)c & \multicolumn{2}{|c|}{$(63 / 128)^{c}$} \\
\hline Einkennalausir & $8(13) \mid 0,3 \pm 0,5$ & $9(15) \mid 0,3 \pm 0,5$ \\
\hline Betri & $26(43) \mid 3,9 \pm 2,1$ & $28(47) \mid 3,3 \pm 1,7$ \\
\hline Óbreyttir & 23 (39) $17,8 \pm 2,1$ & $20(33) \mid 7,4 \pm 2,4$ \\
\hline Verri & 3 (5) | --------- & 6 (10) | --------- \\
\hline \multicolumn{3}{|c|}{ 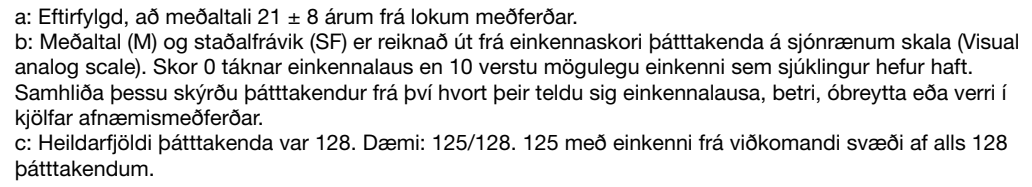 } \\
\hline
\end{tabular}

Klárt samband verður að vera til staðar milli einkenna og pess ofnæmisvaka sem afnæma á fyrir. Erfitt er að forðast grasfrjó og jafnframt eru ofnæmisvakar frá köttum dreifðir í flestum húsum á Reykjavíkursvæðinu og valda pví einkennum allt árið. Hins vegar finnast rykmaurar ekki á Reykjavíkursvæðinu og pví er afnæming ópörf fyrir peim á pví svæði. ${ }^{12}$

Hvernig hefðbundin lyfjameðferð polist og virkar. Pó svo að langflestir poli vel hin hefðbundnu ofnæmislyf geta hliðarverkanir og/eða virkni lyfjanna gert pað að verkum að afnæming sé besti meðferðarkosturinn.

Aldur. Í Bandaríkjunum er ekki ráðlagt að hefja afnæmingu á börnum yngri en 5 ára. Ekki eru til nein efri aldursmörk, en rétt er að hafa í huga að hjarta- og æðasjúkdómar geta verið frábending fyrir slíkri meðferð.

Afnæmismeðferð er ekki hættulaus og par vegur pyngst hættan á ofnæmislosti sem getur komið fram á öllum stigum meðferðar. ${ }^{13,14}$

Sjúklingar með illa meðhöndlaðan astma ættu síður að gangast undir afnæmismeðferð vegna aukinnar áhættu á slæmum astmaköstum meðan á henni stendur. ${ }^{15}$ Afnæmismeðferð er talin valda alvarlegum kerfisbundnum aukaverkunum, раð er astma eða blóðprýstingsfalli, í um 0,05-3,2\% tilfella par sem afnæming er gefin. Banvæn viðbrögð eru talin koma fram í einu af hverjum 2-2,5 milljón tilfella. ${ }^{16}$

Tilgangur rannsóknarinnar var að fá upplýsingar um heildarfjölda peirra sem fengið höfðu afnæmismeðferð gegn ofnæmi á Landspítala á tímabilinu 1977-2006. Áhersla var lögð á mat langtímaárangurs meðferðarinnar með tilliti til kyns, aldurs, ofnæmis sem meðhöndlað var, astma og annarra ofnæmissjúkdóma.

\section{Efniviður og að̆ferôir}

\section{Rannsóknarhópur}

Rannsóknarhópurinn samanstóð af einstaklingum sem hófu afnæmismeðferð gegn ofnæmi á göngudeild astma- og ofnæmissjúkdóma á Landspítala á árunum 1977-2006. Alls hófu 289 manns meðferð á tímabilinu. 38 sögðu sig úr meðferð innan við sex mánuðum eftir að hún hófst og voru par af leiðandi undanskildir pátttöku. 251 uppfyllti pátttökuskilmerki. Kynningarblöð og staðlaður spurningalisti var sent í pósti til sjúklinga með lögheimili á Íslandi og samband haft við pá símleiðis um einni til premur vikum síðar. 169 svöruðu síma og sampykktu alls 128 pátttöku í rannsókninni (76\%) (mynd 1). 
Sjúkraskrár

Úr sjúkraskrám sjúklinga fengust upplýsingar um hvenær meðferð hófst, í flestum tilfellum hversu lengi hún stóð og gegn hverju var afnæmt. Ekki lágu fyrir nákvæmar upplýsingar um hvaða efni voru notuð við afnæminguna.

\section{Árangursmat}

Spurningalisti var lagður fyrir pátttakendur par sem spurt var um fyrra heilsufar, ættarsögu um ofnæmi eða astma meðal fyrstu gráðu ættingja, pað er börn, foreldrar eða systkini, ofnæmislyfjanotkun, ofnæmiseinkenni og einstaka áhættupætti astma og ofnæmis. Jafnframt var sérstök áhersla lögð á hugsanlegar hliðarverkanir meðferðarinnar. Við mat á virkni meðferðarinnar var lögð áhersla á einkenni ofnæmis. Pátttakendur svöruðu spurningum með einkunnagjöf á sjónrænum skala (visual analog scale) par sem 0 táknaði engin einkenni, og 10 verstu mögulegu einkenni sem pátttakandi hafði haft fyrir meðferð. Pátttakendur sögðu einnig til um hvort peir álitu sig vera einkennalausa, betri, óbreytta eða verri.

Við mat á árangri var tekið mið af tveimur tímapunktum; I. strax að meðferð lokinni og II. við eftirfylgd pegar pátttakendur svöruðu spurningalista.

\section{Húðpróf}

Pátttakendur voru húðprófaðir með pikkprófi fyrir vallarfoxgrasi (Phleum Pratense), birki (Betula Verrucosa), köttum og rykmaurum (Dermatophagoides farinae, Dermatophagoides pteronyssinus). Allir ofnæmisvakar voru af gerðinni Soluprick og fengnir frá ALK-Abelló ${ }^{\circledR}$ i Horsholm, Danmörku. Stærð pinu (wheel) og roða (flare) var mælt í millimetrum (mm). Auk pess var svörun við jákvæðu (histamín) og neikvæðu (burðarefni án ofnæmisvaka) viðmiði mæld. Svörun $\geq 3 \mathrm{~mm}$ var metin sem jákvæð, en $<3$ mm neikvætt).

\section{Tölfræði}

Auk hefðbundinna tölfræðilegra útreikninga var tvíhliða Wilcoxons t-prófi beitt. Kí-kvaðrat próf var notað við samanburðarmat á hópum. Allar niðurstöður par sem p-gildi var minna en 0,05 voru álitnar marktækar. Notast var við SPSS tölfræðiforritið.

Rannsóknin var gerð í samræmi við ákvæði Helsinkisáttmálans um vísindarannsóknir á mönnum og sampykkt af Vísindasiðanefnd og Persónuvernd.

\section{Niðurstöةur}

Á 30 ára tímabili (1977-2006) hófu 289 einstak-

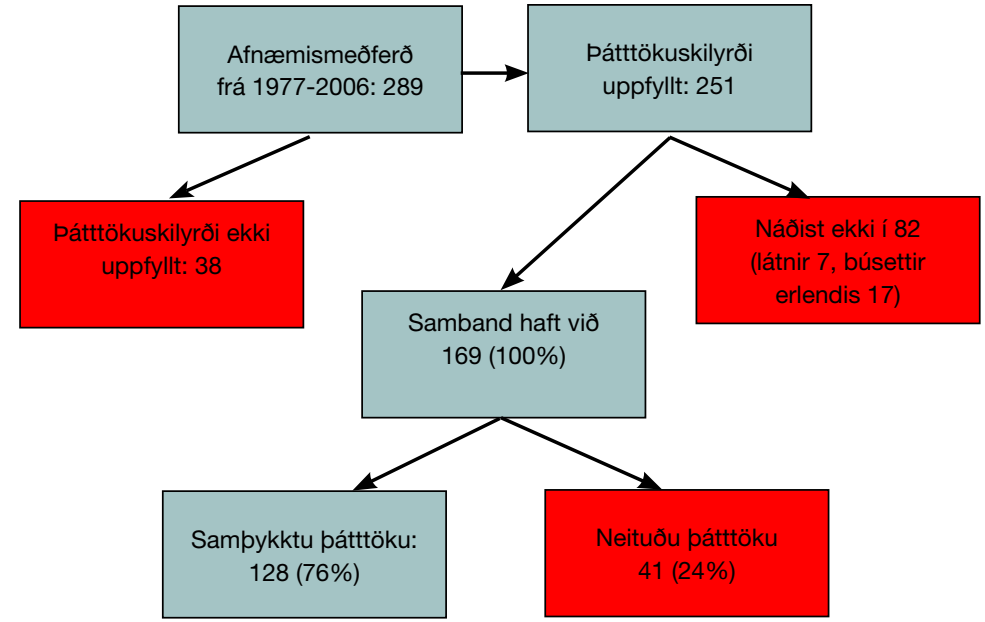

Mynd 1. Flæðirit sem lýsir hvernig lokafjöldi sjúklinga, 128, var fenginn. Í rauðu kössunum er fjöldi peirra sem ekki tók pátt í rannsókninni.
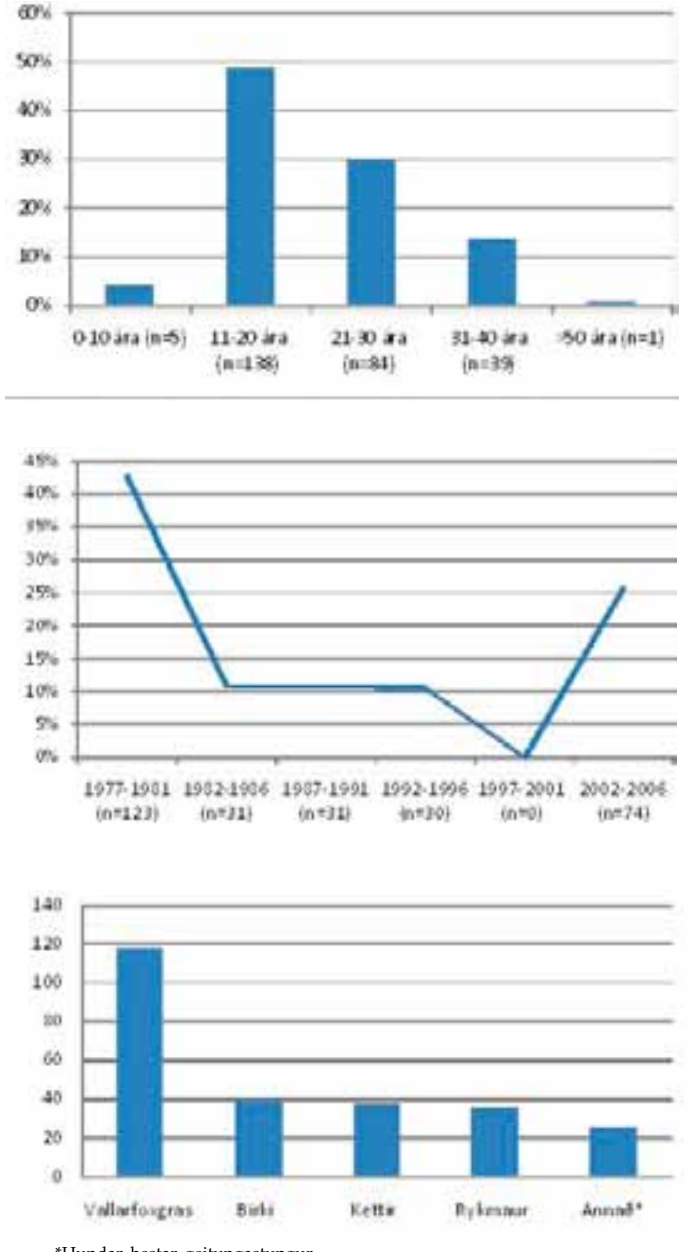

lingar, 164 karlar og 125 konur, afnæmingu á göngudeild astma og ofnæmis, fyrstá Vífilsstöðum sem síðar varð hluti Landspítala. Skiptingu í aldurshópa má sjá á mynd 2. Fjölmennasti aldurshópurinn var 11-20 ára. Í töflu I koma fram lýðfræðilegar upplýsingar um pátttakendur í rannsókninni.
Mynd 2. Aldursskipting við upphaf afnæmismeðferðar á göngudeild astma og ofnæmis á Landspítala. Tölur í sviga tákna fjölda î hoerjum hópi.

Mynd 3. Fjöldi (sýnt sem hluti af heild (\%)) sem hóf afnæmismeðferð’ á göngudeild astma og ofnæmis á Landspítala á hverju 5 ára tímabili frá 1977-2006. Tölur innan sviga tákna fjölda einstaklinga.

Mynd 4. Fjöldi afnæmdra gegn mismunandi ofnæmisvökum. 
Tafla III. Niðurstöður húðprófa.

\begin{tabular}{lcccc}
\hline & Heildarfjöldi afnæmdra & Jákvætt $^{\mathrm{a}}$ & Neikvætt $^{\mathrm{b}}$ & Ný svörun $^{\mathrm{c}}$ \\
\hline Vallarfoxgras, n: & 118 & 114 & 4 & 2 \\
\hline Birki, n: & 38 & 15 & 23 & 14 \\
\hline Kettir, n: & 39 & 34 & 5 & 36 \\
\hline Reykmaur, n: & 36 & 8 & 28 & 5
\end{tabular}

a: Afnæmdir einstaklingar með jákvætt húðpróf.

b: Afnæmdir einstaklingar með neikvætt húðpróf.

c: Einstaklingar með jákvætt húðpróf gegn ofnæmisvaka sem ekki var afnæmt gegn.

Sjúklingar sem fengu fulla meðferð voru að meðaltali meðhöndlaðir í prjú til fimm ár. Á mynd 3 sést hvernig fjöldi meðhöndlaðra dreifist yfir 5 ára tímabil frá 1977-2006.

Á rannsóknartímabilinu var algengast að afnæmt væri gegn vallarfoxgrasi, birki, köttum og rykmaur. Í flestum tilfellum var afnæmt gegn vallarfoxgrasi og fengu 92,2\% pátttakenda slíka meðferð. Í heildina voru sjö mismunandi ofnæmisvakar notaðir til afnæmingar. Í tilvikum hesta-, hunda- og geitungaofnæmis var hlutfall afnæmdra á bilinu 1-10\% og pví ekki hægt að leggja tölfræðilegt mat á árangur afnæmingar gegn pessum ofnæmisvökum sérstaklega (mynd 4).

Við eftirfylgni var hlutfall peirra sem voru einkennalausir 65,3\%. Jafnframt hafði fækkað í peim hópi sem taldi ofnæmiseinkenni sín óbreytt við lok meðferðar úr 35,8\% í 28,5\%, p=0,05, tafla II. Marktækur munur var á fjölda einkennalausra og peirra sem versnuðu, $\mathrm{p}=0,01$.

\section{Áhrifapættir á árangur meðferðar}

Karlar voru oftar einkennalausir, samanborið við konur, pegar ofnæmiseinkenni voru metin við eftirfylgd, $\mathrm{p}=0,03$.

Ekki var hægt að sýna fram á að fjölpætt heilsufarssaga, önnur en um ofnæmi eða astma, hefði áhrif á árangur afnæmismeðferðar.

Ættarsaga um ofnæmi takmarkaðist við fyrstu gráðu ættingja. 60,9\% pátttakenda voru með slíka sögu og ekki var munur milli kynja. Peir sem urðu einkennalausir voru í 70\% tilfella með ættarsögu um ofnæmi marktækt oftar en peir sem ekki höfðu jákvæða ættarsögu, p=0,02.

Einstaklingar með ofnæmi fyrir vallarfoxgrasi eða rykmaurum urðu frekar einkennalausir en peir sem voru með ofnæmi fyrir birki eða köttum, $\mathrm{p}=0,04$.

Við eftirfylgd kvörtuðu 27\% undan ofnæmiseinkennum frá öðrum ofnæmisvökum en peim sem afnæmt hafði verið gegn.

Einkennalausir reyktu frekar/eða höfðu reykt samanborið við pá sem voru verri af ofnæmiseinkennum sínum (55\% vs. 40\%), p=0,02.
Alls voru 28 (22\%) með astma pegar meðferð hófst en við lok meðferðar höfðu níu orðið einkennalausir. Einstaklingar með kattarofnæmi urðu síður einkennalausir $(p=0,03)$ og auk pess fengu einstaklingar með kattarofnæmi, sem ekki var afnæmt fyrir ( $n=16 / 36,44,4 \%)$, frekar astma á rannsóknartímabilinu, $\mathrm{p}=0,03$. Peir sem próuðu með sér astma voru jafnframt oftar með verri ofnæmiseinkenni frá efri loftvegum samanborið við einstaklinga án astma, $\mathrm{p}=0,01$.

Allir pátttakendur voru húðprófaðir gegn fjórum ofnæmisvökum; vallarfoxgrasi, birki, köttum og rykmaurum. Alls voru 118 afnæmdir gegn vallarfoxgrasi. Við eftirfylgni voru 114 enn með jákvætt húðpróf en fjórir sýndu enga svörun. Pá voru tveir sem ekki höfðu verið afnæmdir fyrir grasi með jákvætt vallarfoxgras húðpróf við eftirfylgni. Í töflu III eru niðurstöður húðprófa teknar saman.

Alls luku 102 pátttakendur af 128 í pessari rannsókn $(79,7 \%)$ að minnsta kosti priggja ára afnæmis-meðferð. 26 manns hættu og voru ástæður brotthvarfs einkum prjár; 1) aukaverkanir (11), 2) pungun (6 konur), 3) án ástæðu (9 einstaklingar). Algengustu aukaverkanir ( $n=128)$ voru húðbólgur við stungustað $(68 \%)$, ofnæmislost $(8,6 \%)$ og ofsakláði (7\%). Ekkert dauðsfall var skráð.

\section{Umræða}

Hér hafa verið kynntar niðurstöður rannsóknar sem lagði mat á árangur afnæmismeðferðar á Íslandi á 30 ára tímabili, frá 1977 til 2006. Alls tóku 128 einstaklingar sem höfðu fengið meðferð á göngudeild astma og ofnæmis á Landspítalanum pátt í rannsókninni. Rannsóknin leiddi í ljós að árangur afnæmismeðferðar er raunverulegur og viðvarandi allt að 20 árum eftir að meðferð lýkur. Karlar fengu oftar meiri bata en konur og var munur milli kynja marktækur.

Greinarhöfundar veltu upp peirri spurningu hvort ákveðnar lýðbreytur og/eða áhættupættir gætu haft áhrif á árangur meðferðarinnar. Karlkyn, jákvæð ættarsaga, ofnæmi gegn grasi eða rykmaurum og reykingar höfðu öll jákvæð áhrif á árangur meðferðarinnar. Munur á árangri karla og kvenna er ekki að fullu ljós og parfnast frekari rannsókna.

Tímalengd meðferðar hafði einnig áhrif á árangur og benda niðurstöður til að ákjósanlegast sé að meðferð standi yfir í prjú til fimm ár svo að fullnægjandi árangur fáist. Meðferð stóð yfir í skemmri tíma í um 20\% tilfella og var ástæða brottfalls yfirleitt lélegur skammtímaárangur eða aukaverkanir meðferðar. Athygli vekur að 
að tíðni ofnæmislosts var nokkuð há hjá rannsóknarhópnum eða 8,6\%. Tíðni alvarlegra aukaverkana í erlendum rannsóknum er á bilinu 0,05-3,2\%. ${ }^{16}$ Ástæða pessarar háu tíðni í afnæmismeðferðum hér á landi er ekki að fullu ljós.

Astmi með ofnæmi gegn vallarfoxgrasi batnaði frekar en hjá einstaklingum með ofnæmi gegn köttum. Kattarofnæmi hafði auk pess sterkari tengsl við próun astma samanborið við birki og rykmauraofnæmi. Algengast var að sjúklingar með nýtt ofnæmi væru með húðsvörun fyrir köttum.

Notkun húðprófa við eftirfylgd sjúklinga í afnæmismeðferð er ekki besta leiðin til að meta árangur pó svo að sýnt hafi verið fram á að í kjölfar afnæmingarmeðferðar minnki húoprófssvörun. Pessi breyting í húðsvari er yfirleitt tímabundin og eftir eitt til prjú ár frá lokum meðferðar fer húðprófssvörun að koma til baka og um sex árum frá lokum er talið að húðsvörunin hafi náð fullri fyrri virkni. ${ }^{17,} 18$ Af pessum orsökum er niðurstaða húðprófa ekki lýsandi fyrir árangur afnæmismeðferða og getur pannig skýrt mikinn fjölda jákvæðra húðprófa. Burtséð frá pessu er húðpróf gott greiningartæki á ofnæmi hjá sjúklingum sem ekki hafa fengið afnæmingarmeðferð.

Fjölmargar erlendar rannsóknir hafa verið unnar til að leggja matáárangur afnæmismeðferðar og leiða pær í ljós að afnæming er sérstaklega gagnleg við meðhöndlun á árstíðabundnu ofnæmi. 14, 19, 20 Rannsóknarniðurstöður sýna ennfremur að meðferðin dregur ekki eingöngu úr ofnæmiseinkennum og notkun ofnæmislyfja, heldur hefur hún einnig víðtæk áhrif á meinmyndunarferla í ofnæmi. ${ }^{13,21}$

PAT rannsóknin ${ }^{10}$ var fyrsta rannsókn sinnar tegundar sem lagði mat á hvort afnæming gæti dregið úr ofnæmiseinkennum til lengri tíma og komið í veg fyrir nýmyndun astma hjá börnum með árstíðabundið ofnæmi gegn grasi og birki. Meðferð stóð að meðaltali yfir í prjú ár. Pegar ofnæmiseinkenni pátttakenda og ofnæmislyfjaskor var metið 10 árum eftir að meðferð hófst kom í ljós að marktækur munur var á milli samanburðarhóps sem fengið hafði meðferð með lyfleysu og peirra sem fengið höfðu raunverulega meðferð. Sá bati sem pátttakendur fengu hafði haldist og meðhöndlaðir ofnæmissjúklingar próuðu jafnframt síður með sér astma.

Áhrif afnæmingar á ofnæmissjúklinga með astma hafa verið skoðuð ítarlega. Í rannsókn ${ }^{19}$, ${ }^{22}$ var sýnt fram á marktækan mun milli samanburðarhóps og rannsóknarhóps par sem aðeins 22\% pátttakenda sem voru í samanburðarhópi voru læknaðir af astma samanborið við $72 \%$ peirra sem voru meðhöndlaðir gegn ofnæmi yfir fjögurra ára tímabil. Meðhöndlun á ofnæmiskvefi par sem ýmist var afnæmt gegn grasi eða rykmaurum ${ }^{19},{ }^{23}$ hefur einnig gefið góða raun par sem pessir einstaklingar próa sjaldnar $(p<0,05)$ með sér astma samanborið við ómeðhöndlaða ofnæmissjúklinga.

Í rannsókn frá árinu 1961 ${ }^{19,24}$ var pví lýst hvernig afnæming dró stórlega úr próun nýs ofnæmis meðal sjúklinga sem fengu fjögurra ára afnæmismeðferð. Ekkert peirra barna sem var meðhöndlað fékk ofnæmi ólíkt pví sem gerðist í ómeðhöndluðum samanburðarhópi par sem 25\% próuðu með sér nýtt ofnæmi. Nokkrar rannsóknir hafa lýst svipuðum niðurstöðum. Í peim er almennt talað um að á bilinu 6-27\% afnæmdra prói með sér nýtt ofnæmi samanborið við 38-75\% peirra sem eru með ómeðhöndlað ofnæmi. ${ }^{25-27}$

Meginveikleikar rannsóknarinnar eru helst tveir. Annars vegar skortir samanburðarhóp og hins vegar er rannsóknin afturskyggn og að einhverjum hluta stuðst við minni pátttakenda. Á hinn bóginn er ljóst að mikilvægustu niðurstöður rannsóknarinnar eru ótvíræð og viðvarandi langvinn áhrif meðferðarinnar miðað við núverandi einkenni pátttakenda. Pó svo að notkun samanburðarhóps hefði rennt styrkari stoðum undir niðurstöður rannsóknarinnar má benda á að sambærilegar niðurstöður hafa fengist í erlendum rannsóknum sem ná pó í flestum tilfellum yfir styttri rannsóknartímabil en hér um ræðir.

Í ljósi pess má telja að afnæmismeðferð sé heppilegt meðferðarúrræði fyrir illa meðhöndlanlegt árstíðabundið ofnæmi. Pó verður að hafa í huga alvarlegar aukaverkanir meðferðarinnar og er sérpekking á ofnæmissjúkdómum pví lögð til grundvallar hjá peim sem beita henni.

\section{Pakkir}

Ástu Karlsdóttur hjúkrunarfræðingi og Höllu Jóhannesdóttur hjúkrunarfræðingi á göngudeild astma og ofnæmis á Landspítala er pakkað fyrir mikilvægar upplýsingar og aðstoð við framkvæmd og nálgun rannsóknargagna. Pá er starfsfólki á ónæmisfræðideild Landspítala pakkað fyrir veitta aðstoð. Síðast en ekki síst ber að nefna pá 128 pátttakendur í rannsókninni sem gerðu hana mögulega og er peim pakkað sérstaklega fyrir.

\section{Heimildir}

1. Akdis CA. Allergy and hypersensitivity. Mechanisms of allergic disease. Curr Opin Immunol 2006; 18: 718-26. 
2. Beasley R, Keil U, von Mutius E, et al. Worldwide variation in prevalence of symptoms of asthma, allergic rhinoconjunctivitis, and atopic eczema: ISAAC. Lancet 1998 351: 1225-32.

3. Neukirch F, Pin I, Knani J, et al. Prevalence of asthma and asthma-like symptoms in three French cities. Respir Med 1995; 89: 685-92

4. Haitchi HM, Holgate ST. New strategies in the treatment and prevention of allergic diseases. Expert Opin Investig Drugs 2004; 13: 107-24

5. Rosenwasser LJ. Treatment of allergic rhinitis. Am J Med 2002; 113:17S-24S

6. Larché M, Akdis CA, Valenta R. Immunological mechanisms of allergen-specific immunotherapy. Nature Rev Immunol 2006; 6: 761-71.

7. Akdis M, Akdis CA. Mechanisms of allergen-specific immunotherapy. J Allergy Clin Immunol 2007; 119: 780-9.

8. Adkinson NF Jr. Immunotherapy for allergic rhinitis. N Engl J Med 1999; 341: 468-75.

9. Till SJ, Francis JN, Nouri-Aria K, Durham SR. Mechanisms of immunotherapy. J Allergy Clin Immunol 2004; 113: 1025-34.

10. Jacobsen L, Niggemann B, Dreborg S, et al. Specific immunotherapy has long-term preventive effect of seasona and perennial asthma: 10-Year follow-up on the PAT study. Allergy 2007; 62: 943-8.

11. Vrtala S. From allergen genes to new forms of allergy diagnosis and treatment. Allergy 2008; 63: 299-309.

12. Gíslason D, Guðmundsson G, Tómasson K, Sigurðarsson SP, Hallas T. Maurar í húsryki á íslenskum bóndabæjum. Læknablaðið 2008; 94: 723-7.

13. Malling HJ, Weeke B. Position paper of the European Academy of Allergology and Clinical Immunology. Allergy 1993; 48: 9-35.

14. Pipet A, Botturi K, Pinot D, Vervloet D, Magnan A. Allergenspecific immunotherapy in allergic rhinitis and asthma. Mechanisms and proof of efficacy. Respir Med 2009; In Press.

15. Bousquet J, Hejjaoui A, Dhivert H, Clauzel AM, Miche FB. Immunotherapy with a standardized Dermatophagoides pteronyssinus extract. Systemic reactions during the rush protocol in patients suffering from asthma. J Allergy Clin Immunol 1989; 83: 797-802.

16. Lockey RF, Windom HH. An update on the safety of specific immunotherapy. Curr Opin Allergy Clin Immunol 2008; 8 $571-6$.
17. Jacobsen L, Nüchel Petersen B, Jäwihl, Wenstein HL, Ipsen H. Immunotherapy with partially purified and standardized tree pollen extracts. IV. Results from long-term (6-year) follow-up. Allergy 1997; 52: 914-20.

18. Eng PA, Borer-Reinhold M, Heijnen I, Gnehm HPE. Twelveyear follow-up after discontinuation of preseasonal grass pollen immunotherapy in childhood. Allergy 2006; 61: 198201

19. Jacobsen L, Valovirta E. How strong is the evidence that immunotherapy in children prevents the progression of allergy and asthma? Curr Opin Allergy Clin Immunol 2007; 7: 556-60.

20. Calderon MA, Alves B, Jacobson M, Hurwitz B, Sheikh A, Durham S. Allergen injection immunotherapy for seasonal allergic rhinitis. Cochrane Database Syst Rev 2007: 89.

21. Passalacqua G, Durham SR, Global Allergy A. Allergic rhinitis and its impact on asthma update: Allergen immunotherapy. J Allergy Clin Immunol 2007; 119: 881-91.

22. Johnstone DE, Dutton A. The value of hyposensitization therapy for bronchial asthma in children - a 14-year study. Pediatrics 1968; 42: 793-802

23. Grembiale RD, Camporota L, Naty S, Tranfa CME, Djukanovic $\mathrm{R}$, Marsico SA. Effects of specific immunotherapy in allergic rhinitic individuals with bronchial hyperresponsiveness. Am J Respir Crit Care Med. 2000; 162: 2048-52.

24. Johnstone DE, Crump L. Value of hyposensitization therapy for perennial bronchial asthma in children. Pediatrics 1961; 61: $39-44$

25. Pajno GB, Barberio G, De Luca F, Morabito L, Parmiani $\mathrm{S}$. Prevention of new sensitizations in asthmatic children monosensitized to house dust mite by specific immunotherapy. A six-year follow-up study. Clin Exp Allergy 2001; 31: 1392-7.

26. Purello-D'Ambrosio F, Gangemi S, Merendino RA, et al. Prevention of new sensitizations in monosensitized subjects submitted to specific immunotherapy or not. A retrospective study. Clin Exp Allergy 2001; 31: 1295-302.

27. Marogna M, Spadolini I, Massolo A, Canonica GW, Passalacqua G. Randomized controlled open study of sublingual immunotherapy for respiratory allergy in reallife: clinical efficacy and more. Allergy 2004; 59: 1205-10.

\section{Allergen immunotherapy in Iceland 1977-2006}

Introduction: The prevelance of allery and asthma has increased rapidly over the last 3 decades and is now estimated that $25-30 \%$ of population in Western industrialized countries show symptoms of allergy or asthma. The aim of this study was to reveal the success of allergen immunotherapy (AIT) in Landspitali from 19772006

Material and methods: During the study period a total number of 289 individuals underwent immunotherapy in outpatient clinic of allergy and asthma in Landspítali. A total number of 169 individuals were contacted, of whom 128 (76\%) accepted to participate in the study. The evaluation was based on medical records, standardized questionnaire and skin-prick tests.

Results: Patients were evaluated on the average of 20 years after finishing treatment. 118 (92\%) patients were desensitized to grass pollen, to birch pollen (30\%), cat dander $(30 \%)$ and dust mite (28\%). At the time of the study $67 \%$ reported to be asymptomatic or with greatly improved allergy symptoms. Males had better response to AIT than women $(p=0.04)$. Participants with positive family history of allergy and/or asthma in first degree relatives also reported better response to AIT $(p=0.02)$. Furthermore, AIT to grass pollen and dust mite seemed to be more effective than AIT to cat dander and birch $(p=0.04)$. AIT was also shown to reduce asthma.

Conclusion: AIT for 3-5 years provides significant beneficial effect of allergy and asthma symptoms in patients who undergo such therapy. Finally, it's findings support the notion that AIT may reduce the risk of new allergic manifestations.

Rikardsson SG, Löve YB, Jorgensen GH, Gislason D, Ludviksson BR.

Allergen immunotherapy in Iceland 1977-2006. Icel Med J 2010; 96: 463-8.

Keywords: allergy, allergen immunotherapy, asthma, long term effect.

Correspondance: Björn Rúnar Lúðvíksson, bjornlud@landspitali.is 